\title{
Therapeutic Anti-Angiogenesis for Malignant Brain Tumors
}

\author{
$\begin{array}{llll}\text { M. Kirsch } & \text { T. Santarius } & \text { P. M. Black } & \text { G. Schackert } \\ & \end{array}$ \\ aKlinik und Poliklinik für Neurochirurgie, Technische Universität Dresden, Germany \\ ${ }^{b}$ Neurosurgery, Children's Hospital, Boston, MA
}

Key Words

Angiogenesis - Brain tumor - Metastases ·

Clinical trial

\section{Summary}

Malignant brain tumors, especially malignant gliomas, have a poor prognosis, a fact which has remained unchanged over the last decades despite the employment of multimodal therapeutic approaches. Malignant gliomas are among the most vascularized tumors known and the amount of vascularization has been correlated to their prognosis. Since tumor growth is dependent on concomitant vascularization, recent experimental studies have focused on the use of anti-angiogenic molecules as a novel strategy in brain tumor therapy. Angiogenesis inhibitors target at proliferating endothelial cells and suppress the formation of a sufficient vascular bed. Inhibitors such as TNP-470, suramin and angiostatin have shown their therapeutic potential in experimental studies. In a clinical setting, they could be applied for the treatment of multiple tumors or postsurgically as an adjuvant therapy to prevent recurrence. This article discusses presently available anti-angiogenic agents, emphasizing on substances already in clinical trials.

\author{
Schlüsselwörter \\ Angiogenese $\cdot$ Hirntumoren $\cdot$ Metastasen $\cdot$ Klinische \\ Studien
}

\section{Zusammenfassung}

Maligne Hirntumoren, insbesondere die malignen Gliome, haben trotz multimodaler Therapieansätze eine unverändert schlechte Prognose. Diese Aggressivität korreliert mit der Tatsache, daß maligne Gliome zu den gefäßreichsten Tumoren zählen, die wir kennen. Die Quantifizierung der Gefäßdichte in diesen Tumoren erlaubte die Korrelation zur Überlebenszeit der Patienten. Da das Tumorwachstum von einer begleitenden Neovaskularisierung abhängt, wurden erste experimentelle Therapieansätze durchgeführt, um das Tumorwachstum durch Inhibierung der Neovaskularisierung zu verhindern. Inhibitoren der Angiogenese, z.B. TNP-470, Suramin und Angiostatin hemmen die Proliferation von Endothelzellen und die Ausbildung eines funktionsfähigen Gefäßbettes. Erste experimentelle Ansätze haben ihre tumorstatische Wirksamkeit in vivo bewiesen. Zur klinischen Behandlung wären diese Substanzen in Verbindung mit bestehenden Therapien einsetzbar, insbesondere für die Behandlung multipler Tumoren und zur postoperativen Therapie. Diese Übersichtsarbeit beschreibt die neuesten anti-angiogenen Therapiekonzepte besonders mit Hinblick auf Substanzen, die in ersten klinischen Studien eingesetzt werden.

\begin{tabular}{ll}
\hline KARGER & ( 2001 S. Karger GmbH, Freiburg \\
Fax +49 761 452 07 14 & Accessible online at: \\
$\begin{array}{l}\text { E-mail Information@Karger.de } \\
\text { www.karger.com }\end{array}$ & www.karger.com/journals/onk
\end{tabular}

Dr. med. Matthias Kirsch

Klinik und Poliklinik für Neurochirurgie

Technische Universität Dresden

Fetscherstraße 74, D-01307 Dresden (Germany)

Tel. +49 351 458-37 74, Fax -43 04

E-mail matthias.kirsch@mailbox.tu-dresden.de 


\section{Introduction}

It is well recognized that angiogenesis is essential for tumor growth and development of metastasis. With the exception of avascular leptomeningeal tumor spread, tumors cannot grow beyond a certain size without concurrent extension of their vascular bed. Most current treatment concepts aim at the neoplastic cell compartment and rely on cytoreductive measures. On the contrary, anti-angiogenic treatment focuses on the endothelial cell compartment. Endothelial cells are recruited by solid tumors from the existing vasculature and from endothelial precursor cells. Tumor-associated endothelial cells are non-neoplastic cells although they exhibit some features of malignancy such as proliferation and invasiveness. While heterogenous tumors are prone to resistance through clonal selection, endothelial cells represent a homogenous non-neoplastic cell compartment that is less likely to be subject to resistance. Endothelial cells line the inner part of blood vessels and are easily accessible for circulating drugs, especially in comparison to tumor cells. With special respect to brain tumors, endothelial cells can be targeted independently of the blood-brain barrier.

Solid tumors cannot grow beyond a size of $1-3 \mathrm{~mm}$ in diameter without acquisition of new blood vessels, thus inhibition of angiogenesis would be sufficient to keep a majority of intracerebral solid tumors asymptomatic.

Brain tumors are among the most highly vascularized tumors known [1]. Li et al. [2] in 1994 reported a correlation of microvessel grading with cerebrospinal fluid levels of basic fibroblast growth factor (bFGF), and with the risk of recurrence of death in a variety of pediatric brain tumor types. Leon et al. [3] in 1996 reported a negative correlation between increasing microvessel counts and disease-free survival. They demonstrated that vascularity represents an independent prognostic indicator.

The forementioned data show that tumor-related vessel growth represents an attractive new therapeutic target. A number of anti-angiogenic treatment strategies have been developed and will be discussed.

\section{Positive Regulators of Angiogenesis}

Angiogenesis is a complex multifaceted biological process and, thus, offers potential therapeutic targets at multiple levels. After neoplastic transformation of a normal cell has occurred, proliferation ensues. As long as proliferation and cell death remain balanced, the tumor does not expand nor does it need in-growing vessels [4]. This dormant state is of variable duration and ends as soon as angiogenic signals are released and neovascularization ensues, this phenomenon is referred to as the angiogenic switch. Angiogenic growth factors produced by tumor cells induce endothelial cell proliferation. Along with the properties of the surrounding matrix, growth factors determine the success of tumor-related angiogenesis and en-
Table 1. Angiogenic factors

\author{
Acidic and basic FGF (aFGF, bFGF) \\ Transforming growth factor alpha and beta \\ (TGF- $\alpha$ and $-\beta$ ) \\ Angiogenin \\ Epidermal growth factor (EGF) \\ Scatter factor / HGF \\ Placenta-derived growth factor (PlGF) \\ Interleukin-8 (Il-8) \\ Tumor necrosis factor (TNF) \\ Insulin-like growth factor (IGF) \\ Platelet derived growth factor (PDGF) \\ Prostaglandins $\mathrm{E}_{1}$ and $\mathrm{E}_{2}$ \\ Androgen, estrogen \\ Angiopoietin-1 (ANG-1) \\ ANG-2 in the presence of VEGF
}

dothelial cell recruitment. A growing number of molecules with angiogenic properties produced by tumor cells as well as endothelium-specific angiogenic molecules have been identified. While a comprehensive list is given in table 1, this overview focuses mainly on molecules that are already subject of clinical investigation.

\section{$V E G F$ and VEGF Receptors}

Vascular endothelial growth factor (VEGF) represents an important signal molecule during initiation and maintenance of angiogenesis by hypoxia [5]. The VEGF receptors belong to a family of endothelial receptor tyrosine kinases which are activated upon high-affinity binding of the growth factors to their cognate receptors. VEGF and its receptors are expressed at high levels in many types of human tumors, including gliomas [6], where they exhibit a cell-type specificity [7]. Whereas VEGF is secreted by tumor cells as well as by normal tissue in response to hypoxia, the VEGF receptor KDR/flk-1 is expressed on the surface of activated endothelial cells, especially at tumor sites [8]. Forced overexpression of VEGF by tumor cells has been shown to enhance their tumorigenic potential $[5,9]$. The cellular effects of VEGF are mediated by at least three different receptors VEGF-R-1, -2 , and -3 , also termed flt-1, flk-1/KDR, and flt-4, respectively. In addition, VEGF expression has been shown to represent an independent prognostic factor for the outcome of pancreatic, ovarian, and mammary ductal carcinoma in situ, as well as of metastasizing testicular cancer and of brain tumors [10].

In brain tumors, VEGF was shown to be overexpressed in gliomas compared to normal tissue [7, 10, 11]. Furthermore, expression of VEGF has been reported to correlate with microvessel density in gliomas and meningiomas [10]. Consistent with its regulatory role in vessel permeability, VEGF expression also correlates with tumorigenic edema in cerebral metastases, meningiomas, and gliomas [12-15]. Based on immunohistochemical expression data on 162 astrocytic gliomas, VEGF expression has been correlated with overall survival 
Table 2. Angiogenesis inhibitors in clinical trials

\begin{tabular}{|c|c|c|c|}
\hline Drug & Trial & Mechanism & Company \\
\hline Marimastat & phase III & synthetic inhibitor of MMPs & British Biotech \\
\hline AG-3340 & phase II + III & synthetic inhibitor of MMP-2/-9 & Agouron \\
\hline COL-3 & phase I + II & synthetic inhibitor of MMPs & Collagenex \\
\hline Neovastat & phase I + II & endogenous inhibitor of MMPs & Aeterna \\
\hline BMS-275291 & phase I & synthetic inhibitor of MMPs & Bristol-Myers Squibb \\
\hline CGS-27023A & phase I + II & synthetic inhibitor of MMPs & Novartis \\
\hline Bay-12-9566 & phase III & synthetic inhibitor of MMP-2 /-9 & Bayer \\
\hline TNP-470 & phase I + II & Fumagillin-analogue & TAP pharmaceuticals \\
\hline Thalidomide & phase I + II + III & inhibits EC proliferation; & \\
\hline \multirow[t]{2}{*}{ Squalamine } & phase I + II & $\begin{array}{l}\text { inhibits EC activation via monocyte by TNF } \alpha \text { blockade } \\
\text { extract from shark liver; }\end{array}$ & Celgene \\
\hline & & inhibits sodium-hydrogen exchanger, NHE3 & Magainin Pharmaceuticals \\
\hline Combrestatin A-4 prodrug & phase I + II & apoptosis of endothelial cells & Oxigene \\
\hline Endostatin & phase I & inhibits endothelial proliferation & Entremed \\
\hline Angiostatin & phase I & inhibits EC proliferation & Entremed \\
\hline SU5416 & phase I + II + III & blocks VEGF receptor signaling & Sugen \\
\hline SU101 & phase III & blocks PDGF receptor signaling & Sugen \\
\hline SU6668 & phase I & blocks VEGF, FGF, PDGF receptor signaling & Sugen \\
\hline Interferon-a & phase II + III & inhibition of bFGF, VEGF, and MMP-9 production & Multiple vendors \\
\hline Interferon- $\beta$ & phase II + III & inhibition of endothelial cell migration and morphogenesis & Multiple vendors \\
\hline Anti-VEGF Ab & phase I + II & humanized monoclonal antibody to VEGF & Genentech \\
\hline EMD121974 & phase I & blocks $\alpha_{v} \beta_{3}$ integrins on $\mathrm{EC}$ & Merck KcgaA Darmstadt \\
\hline CAI & phase I + II + III & inhibits $\mathrm{Ca}++$ influx & National Cancer Institute, USA. \\
\hline Interleukin-12 & phase I + II & upregulation of interferon- $\gamma$ and IL-10 & Genetics Institute \\
\hline \multirow[t]{2}{*}{ IM-862 } & phase I + II + III & upregulates IL-12; & \\
\hline & & inhibits VEGF and bFGF production & Cytran \\
\hline IMC-C225 & phase I + II + III & humanized monoclonal antibody to the EGF receptor & ImClone \\
\hline IMC-1C11 & phase I & humanized monoclonal antibody to the VEGF receptor KDR & ImClone \\
\hline Vitaxin & phase I & humanized monoclonal antibody to the $\alpha_{v} \beta_{3}$ integrin & MedImmune / Ixsys \\
\hline Anti-VEGF Ab & phase II + III & humanized monoclonal antibody to VEGF & Genentech \\
\hline Suramin & phase II & prevents PDGF binding & Multiple vendors \\
\hline $\begin{array}{l}\text { Troponin-I, BLS } 0597 \\
\text { (fragment of troponin I) }\end{array}$ & phase I & inhibits EC proliferation, binds ATP synthase & Boston Life Sciences \\
\hline Angiozyme & phase I & ribozyme degrades VEGF mRNA & Ribozyme \\
\hline PTK787 / ZK-222584 & phase I & specific inhibitor of FLK-1 and KDR receptor for VEGF & Novartis, Schering \\
\hline Pentosan polysulfate & phase I & downregulates bFGF production & Georgetown University, Washington \\
\hline ZD-0101 & phase I + II & endotoxin binds to EC and induces antiinflammatory & AstraZeneca / CarboMed \\
\hline \multirow[t]{2}{*}{ CM-101 } & & response & \\
\hline & & VEGF and VEGF-R2 downregulation & \\
\hline
\end{tabular}

but was not shown to be an independent prognostic factor in gliomas [16]. In low-grade astrocytomas, however, VEGF expression correlates with the outcome [17].

Several lines of experimental evidence suggest that targeting VEGF may lead to highly effective anti-angiogenic treatment. Thus, antibodies against VEGF, VEGF-R, and VEGF-diphtheria toxin conjugates exert an inhibitory effect on the growth of tumor xenografts in mice [18-20]. The retroviral introduction of VEGF antisense-RNA into glioma cells in a mouse model resulted in the inhibition of tumor growth and prolongation of survival time [21]. A $16 \mathrm{kDa}$ prolactin fragment has been demonstrated to interfere with VEGF-induced signalling pathways by inhibiting phosphorylation of two mitogen-activated protein kinases (MAPK) by VEGF [22]. Whether this endogenously produced anti-angiogenic mole- cule can be employed for therapeutic use remains to be investigated.

Antibodies against human VEGF and VEGF receptors are currently being tested in phase II/III clinical trials (table 2). While some of the recently reported VEGF-R antagonists such as the porphyrin antagonist TMPP or short peptides identified by phage display have not yet reached the clinical arena, other low-molecular-weight inhibitors of VEGF-R tyrosine kinases such as SU5416, SU6668, PTK787, and ZD4190 are already under clinical investigation (table 2).

\section{Tie - Receptors and Angiopoietins}

Tie- 1 and Tie-2, tyrosine kinases with immunoglobulin and epidermal growth factor homology domains, resemble the VEGF receptors in that they constitute endothelial-cell-spe- 
Table 3. Endogenous inhibitors of angiogenesis
Interferons, esp. interferon- $\alpha$ and $-\beta$

PF4 (platelet-derived factor 4)

Thrombospondin-1

Metallospondin

TIMPs (tissue inhibitors of metalloproteinases)

Plasminogen activator/inhibitor

ANG-2 (angiopoietin-2) in absence of VEGF

SPARC (secreted protein, acidic and rich in cysteine)

Angiostatin (cleaved from plasminogen)

Endostatin (cleaved from collagen XVIII)

PEX (cleaved from MMP-2)

$\mathrm{N}$-terminal fragment of anti-thrombin III

$16-\mathrm{kDa}$ fragment of prolactin

Tn-1 (cleaved from Troponin-1)

Vasostatin (cleaved from calreticulin)

AaAT111 (cleaved from ATIII)

Arresten (cleaved from collagen type IV)

Canstatin (cleaved from collagen type IV)

Restin (cleaved from collagen type XV)

N-terminal fragment of platelet factor 4

Proliferin-related protein

(cleaved from proliferin) cific surface receptors with tyrosine kinase activity. The physiologic function of Tie receptors and their ligands, called angiopoietins (ANG), in angiogenesis has only recently been elucidated. ANG-1, the major physiologic activator of Tie-2, promotes blood vessel maturation and stability. ANG-2 counteracts this effect by competitively inhibiting the binding of ANG-1 to Tie-2. Knock-out mice lacking the Tie receptors did not survive beyond embryonic stages [23]. While Tie-1-1- mice failed to establish the structural integrity of vascular endothelial cells leading to localized hemorrhage, Tie- $2^{-/}$mice displayed significant abnormalities in growth and organization of the vasculature [23]. Upregulation of ANG-2 by hypoxia occurs in endothelial cells in vitro and in vivo [24]. Counteracting VEGF-induced permeability, ANG-1 functions as an antipermeability factor when administered chronically during vessel formation $[25,26]$.

Expression of ANG-1 or ANG-2 has not been detected in normal brains. However, upregulation of Tie-2-receptor mRNA and ANG-2 mRNA was demonstrated in endothelial cells of glioma vasculature, while ANG-1 was found to be upregulated in glioma cells suggesting a role for angiopoietins in glioma angiogenesis [27-29]. Application of the soluble extracellular domain of Tie-2-inhibited angiogenesis in the rat cornea, as well as tumor growth in a skin window chamber [30]. Adenoviral delivery of a recombinant, soluble Tie-2 receptor suppressed murine mammary carcinoma or melanoma growth and development of metastasis in mice [31].

\section{Integrins and Matrix Metalloproteinases}

Invasion and migration requires a complex interaction between tumor cells and extracellular matrix (ECM) compo- nents. Tumor cell invasion involves cell-matrix adhesion, chemotaxis, cell migration and proteolysis. Endothelial cells interact with ECM proteins such as fibronectin via specific receptors expressed on their cell surface. They eventually invade and dissolve the basement membrane and the surrounding matrix by secretion of enzymes. This proteolytic degradation of the ECM plays a central role in cancer invasion as well as in non-neoplastic remodeling processes. The integrin family of heterodimeric glycopeptides, particularly $\alpha_{v} \beta_{3}$ and $\alpha_{v} \beta_{5}$ integrins, serve as major receptors for ECM-mediated cell adhesion and migration. $\alpha_{v} \beta_{3}$ and $\alpha_{v} \beta_{5}$ integrins have been demonstrated to be upregulated during repair, retinal neovascularisation, and tumor neo-angiogenesis [32, 33]. $\alpha_{v} \beta_{3}$ integrins are expressed in small blood vessels of glioblastoma [34]. Antibodies to a variety of integrins have been shown to inhibit matrigel invasion of glioma cell lines and primary cultures [35].

Among the key enzymes which participate in ECM degradation are the metalloproteases (MMP), zinc-binding endopeptidases such as MMP-2 and MMP-9, and serine proteases such as tissue plasminogen activator (tPA) and urokinase plasminogen activator (uPA). MMPs are secreted as inactive proenzymes and become activated at the site of action, e.g. the tumor cell. An imbalance between MMPs and their naturally occurring inhibitors, so-called tissue inhibitors of metalloproteinases (TIMP) has been observed in a variety of tumors, including brain tumors [36-39]. The serine proteases, tPA and uPA, activate the proenzyme plasminogen to plasmin, which in turn is responsible for fibrinolytic activity. Consistent with their role in cancer spread, elevated levels of both enzymes have been associated with poor prognosis in a variety of tumors.

Matrix metalloproteinase- 2 and integrin $\alpha_{v} \beta_{3}$ are functionally associated on the surface of angiogenic blood vessels. MMP-2 (also called collagenase IV or gelatinase A) has been shown to cleave type IV collagen, the major structural component of basement membranes, with high specificity. Moreover, the metastatic potential of tumor cells has been correlated with the activity of this enzyme [40]. Short peptides which target MMP-2 and MMP-9 inhibited the migration of human endothelial and tumor cells and improved survival of mice bearing human tumors [41]. Synthetic MMP inhibitors such as Marimastat, Batimastat, AG3340, Bay 12-9556, and others are already subject of clinical trials.

\section{Endogenous Inhibitors}

Only recently we have witnessed the discovery of a number of naturally occuring endogenous inhibitors of angiogenesis. Besides primarily anti-angiogenic molecules such as platelet-derived factor 4 , or thrombospondin-1, a growing number of anti-angiogenic factors such as angiostatin and endostatin represent proteolytic fragments of proteins with various functions that may be unrelated to angiogenesis (table 3 ). 


\section{Thrombospondin}

Activated platelets, endothelial cells, and fibroblasts release several thrombospondin isoforms (TSP 1-4), a 450-kD homotrimeric glycoprotein with a broad tissue distribution. TSP1 and TSP-2 were shown to inhibit endothelial cell proliferation, angiogenesis, and tumor growth $[42,43]$. The p53 gene, a major cell cycle regulator and tumor-suppressor gene, was proposed to inhibit angiogenesis by regulation of TSP-1 synthesis [44]. This finding is of special interest, as loss of p53 is a common event in human cancer, especially in glioma. Upon introduction of a wild-type chromosome 10 into 3 human glioblastoma cell lines, their ability to form tumors in nude mice was lost and an anti-angiogenic phenotype was acquired [45]. Although chromosome 10 harbors a number of potential tumor-suppressor genes, including the PTEN gene, the observed change in angiogenesis was thought to be attributable to the induction of thrombospondin- 1 secretion, because a neutralizing thrombospondin antibody completely relieved the inhibition [45]. Similarly, thrombospondin-2 was shown to be a potent inhibitor of angiogenesis and tumor growth in mice after transfection into squamous cell carcinoma cells, although its expression did not alter tumor cell proliferation or apoptosis in vitro [43]. Moreover, the combined overexpression of TSP-1 and TSP-2 completely prevented tumor formation in this model [43]. Recently, short peptide fragments originating from the TSP protein have been shown to exhibit similar anti-angiogenic properties and, thus, represent potential candidates for the use in anti-angiogenetic therapy [46, 47].

\section{Angiostatin}

The discovery of the first highly specific anti-angiogenic molecule, termed angiostatin, by O'Reilly et al. [48] has highlighted the central role of angiogenesis in tumor development. This initiated a search for new endogenous inhibitors of tumor-related angiogenesis. The search for an endogenous inhibitor of tumor growth was based on the observation that metastases began to grow after the removal of the original solid tumor. When serum and concentrated urine from Lewis lung cell (LLC) carcinoma bearing mice were given to mice that had undergone removal of a solid LLC, a significant suppression of metastases was observed suggesting the presence of a soluble growth inhibitory mediator in these fluids. Interestingly, serum and urine from LLC-bearing mice inhibited endothelial cell proliferation, but had no effect on tumor cell proliferation in vitro. The purified mediator, termed angiostatin, was identified as a $38-\mathrm{kDa}$ amino-terminal fragment of plasminogen spanning the first 4 kringle domains of plasminogen [48]. Further investigations have shown that kringles 1-3 harbour the endothelial cell inhibitory function, whereas kringle 4 had little effect $[49,50]$. However, a longer plasminogen fragment encompassing kringles 1-5 is also an effective inhibitor of endothelial cells and of tumor growth [51]. The observation of angiostatin-induced apoptosis of endothelial but not of tumor cells, indicates that endothelial cells and endothelial precur- sor cells are exclusive cellular targets of angiostatin [48, 52]. In addition, angiostatin has been shown to inhibit endothelial cell migration and invasion, as well as tube formation in vitro [50, 53]. Angiostatin therapy keeps LLC lung metastases in a dormant state which is characterized by insufficient vascularisation and high proliferation balanced by a high apoptotic rate $[4,48,54]$. Subcutaneous and intracerebral gliomas of both rat and human origin were successfully treated in a nude mouse model by systemic administration of angiostatin $[55,56]$. In addition, retroviral or adenoviral transduction of the angiostatin gene into established brain tumors in mice inhibited tumor growth effectively $[57,58]$. To date, many other extracerebral tumor types have been demonstrated to respond with growth inhibition to systemic application of angiostatin in vivo $[4,48,54]$. Furthermore, the administration of angiostatin in conjunction with ionizing radiation resulted in synergistic effects of the two modalities in 4 different cancer types in mice including mouse LLC, human prostate and larynx squamous cell carcinomas, as well as human D54 glioma [59, 60].

\section{Endostatin}

Using an experimental approach similar to that used for the isolation of angiostatin, O'Reilly et al. [61] isolated endostatin, a $22-\mathrm{kDa}$ carboxy-terminal fragment of collagen XVIII $\alpha 1$, from a murine hemangioendothelioma. Similarly to angiostatin, it acts anti-angiogenic by induction of apoptosis and specific inhibition of proliferation, migration, and tube formation of endothelial cells [61-63]. Endostatin has successfully been used systemically or by gene transfer to treat a variety of cancers including fibrosarcoma, melanoma, hemangiothelioma, prostate, renal, mammary, lung, and colon carcinoma [61]. Treatment of mice carrying fibrosarcoma, melanoma or LLC with exogenously administered endostatin for several cycles resulted in a permanent size reduction of tumors into small, dormant nodules [64]. The combined application of angiostatin and endostatin has shown synergistic effects on tumor suppression indicating that the molecular targets differ between the two inhibitory molecules [65]. Recombinant endostatin is currently subject of clinical trials for a variety of cancers (table 2).

\section{Synthetic Anti-Angiogenic Factors}

\section{Suramin}

Suramin was initially introduced 80 years ago as a potent antitrypanozomal agent. Only recently, it was shown to inhibit binding of platelet derived growth factor (PDGF) to its receptor by binding to PDGF directly [66]. Thus, suramin acts antiangiogenic by disrupting the PDGF feedback loop operating in many tumors, including brain tumors [67]. Suramin was also shown to inhibit VEGF-induced tyrosine phosphorylation of KDR in intact cells and to suppress bFGF-induced angiogenesis, tube formation, and matrigel invasion [68]. Its growth sup- 
pressive properties have been demonstrated for a number of tumors including glioma and meningioma [69-72]. Suramin is under clinical investigation (table 2).

\section{Fumagillin and TNP 470}

Fumagillin is a secreted antibiotic of the fungus Aspergillus fumigatus. Its inhibitory property on endothelial cell proliferation was first noted in contaminated endothelial cell culture dishes. Fumagillin was also shown to inhibit tumor-induced angiogenesis in vivo [73]. More potent synthetic derivatives of fumagillin are TNP-470 or AMG-1470 [74]. TNP-470 has been demonstrated to reduce endothelial cell proliferation by inhibition of urokinase-type plasminogen activator [75]. In addition, it acts growth suppressive on hematopoietic progenitor cells [76]. While there are controversial reports on the effects of TNP-470 on growth suppression of tumor cells in vitro, several in vivo experiments have clearly demonstrated its growthsuppressive effect on primary and metastatic tumor growth, including pituitary adenoma, meningioma, medulloblastoma, and glioma [77-82]. TNP-470 has entered clinical trials for a variety of solid tumors including AIDS-associated Kaposi's sarcoma, prostate, cervical and pancreatic cancers, as well as malignant glioma.

\section{Thalidomide}

Thalidomide was initially developed as a compound to treat morning sickness and headaches of pregnant women, but has become known for its devastating teratogenic effects. Because of its anti-angiogenic properties it is assumed that inhibition of vascular development during embryogenesis accounts for its teratogenicity [83]. While thalidomide inhibits endothelial cell and tumor cell proliferation in vitro, it has variable inhibitory effects on tumor growth and on the migration of metastases $[84,85]$. Thalidomide or its metabolites have been demon- strated to repress the transcriptional activity of genes encoding growth factors and integrins by binding to regulatory promoter sequences. In addition, it was shown to interact synergistically with other chemotherapeutic drugs in vivo. A recent phase II study on the effects of thalidomide in advanced melanoma, renal cell, ovarian and breast cancer has revealed only modest therapeutic effects in renal cell carcinoma with the other tumor types remaining unaffected [86]. However, thalidomide has shown considerable effects even as a single agent in patients with multiple myeloma and hepatocellular carcinoma [87, 88]. Clinical trials for AIDS-related Kaposi sarkoma and other types of cancer are being conducted. The findings of a recently conducted phase II trial on Thalidomide in patients with high-grade gliomas demonstrated low toxicity and only minor responses to treatment [89].

\section{Conclusion}

The promising experimental data on anti-angiogenic intervention in the treatment of cancer, both in vitro and in vivo, for the treatment of experimental primary brain tumors and for metastases warrant clinical investigation of anti-angiogenic substances in human cancer. Compared to conventional chemotherapeutics, anti-angiogenic substances have less toxic side effects and are less likely to develop drug resistance. Especially with regard to the highly vascularized glioblastoma that still carries a dismal prognosis, anti-angiogenic strategies may offer new hope. In a clinical setting therapeutic antiangiogenesis could be applied pre-surgically for devascularization, post-surgically to prevent recurrence of microscopic residual tumor with or without the combination of established cytotoxic drugs or radiation therapy.

\section{References}

1 Brem S, Cotran R, Folkman J: Tumor angiogenesis: A quantitative method for histologic grading. J Natl Cancer Inst 1972;48:347-356.

2 Li VW, Folkerth RD, Watanabe H, Yu C, Rupnick M, Barnes P, Scott RM, Black PM, Sallan SE, Folkman J: Microvessel count and cerebrospinal fluid basic fibroblast growth factor in children with brain tumours. Lancet 1994;344:82-86.

3 Leon SP, Folkerth RD, Black PM: Microvessel density is a prognostic indicator for patients with astroglial brain tumors. Cancer 1996;77:362-372.

4 Holmgren L, O'Reilly MS, Folkman J: Dormancy of micrometastases: Balanced proliferation and apoptosis in the presence of angiogenesis suppression. Nat Med 1995;1:149-153.

5 Damert A, Machein M, Breier G, Fujita MQ, Hanahan D, Risau W, Plate KH: Up-regulation of vascular endothelial growth factor expression in a rat glioma is conferred by two distinct hypoxia-driven mechanisms. Cancer Res 1997;57:3860-3864.
6 Cheng SY, Huang HJ, Nagane M, Ji XD, Wang D, Shih CC, Arap W, Huang CM, Cavenee WK: Suppression of glioblastoma angiogenicity and tumorigenicity by inhibition of endogenous expression of vascular endothelial growth factor. Proc Natl Acad Sci USA 1996;93:8502-8507.

7 Plate KH, Breier G, Weich HA, Risau W: Vascular endothelial growth factor is a potential tumour angiogenesis factor in human gliomas in vivo. Nature 1992;359:845-848.

8 Brown LF, Berse B, Jackman RW, Tognazzi K, Guidi AJ, Dvorak HF, Senger DR, Connolly JL, Schnitt SJ: Expression of vascular permeability factor (vascular endothelial growth factor) and its receptors in breast cancer. Hum Pathol 1995;26: 86-91.
9 Detmar M, Velasco P, Richard L, Claffey KP, Streit M, Riccardi L, Skobe M, Brown LF: Expression of vascular endothelial growth factor induces an invasive phenotype in human squamous cell carcinomas. Am J Pathol 2000;156:159-167.

10 Samoto K, Ikezaki K, Ono M, Shono T, Kohno K, Kuwano M, Fukui M: Expression of vascular endothelial growth factor and its possible relation with neovascularization in human brain tumors. Cancer Res 1995;55:1189-1193.

11 Plate KH, Breier G, Millauer B, Ullrich A, Risau W: Up-regulation of vascular endothelial growth factor and its cognate receptors in a rat glioma model of tumor angiogenesis. Cancer Res 1993;53: 5822-5827.

12 Kalkanis SN, Carroll RS, Zhang J, Zamani AA, Black PM: Correlation of vascular endothelial growth factor messenger RNA expression with peritumoral vasogenic cerebral edema in meningiomas. J Neurosurg 1996;85:1095-101. 
13 Provias J, Claffey K, delAguila L, Lau N, Feldkamp M, Guha A: Meningiomas: Role of vascular endothelial growth factor/vascular permeability factor in angiogenesis and peritumoral edema. Neurosurgery 1997;40:1016-1026.

14 Strugar J, Rothbart D, Harrington W, Criscuolo GR: Vascular permeability factor in brain metastases: Correlation with vasogenic brain edema and tumor angiogenesis. J Neurosurg 1994;81:560-566.

15 Strugar JG, Criscuolo GR, Rothbart D, Harrington WN: Vascular endothelial growth/permeability factor expression in human glioma specimens: Correlation with vasogenic brain edema and tumor-associated cysts. J Neurosurgery 1995;83:682-689.

16 Oehring RD, Miletic M, Valter MM, Pietsch T, Neumann J, Fimmers R, Schlegel U: Vascular endothelial growth factor (VEGF) in astrocytic gliomas - a prognostic factor? J Neurooncol 1999; 45:117-125.

17 Abdulrauf SI, Edvardsen K, Ho KL, Yang XY, Rock JP, Rosenblum ML: Vascular endothelial growth factor expression and vascular density as prognostic markers of survival in patients with lowgrade astrocytoma. J Neurosurg 1998;88:513-520.

18 Borgstrom P, Hillan KJ, Sriramarao P, Ferrara N: Complete inhibition of angiogenesis and growth of microtumors by anti-vascular endothelial growth factor neutralizing antibody: Novel concepts of angiostatic therapy from intravital videomicroscopy. Cancer Res 1996;56:4032-4039.

19 Zhu Z, Witte L: Inhibition of tumor growth and metastasis by targeting tumor-associated angiogenesis with antagonists to the receptors of vascular endothelial growth factor. Invest New Drugs 1999; 17:195-212.

20 Olson TA, Mohanraj D, Roy S, Ramakrishnan S: Targeting the tumor vasculature: Inhibition of tumor growth by a vascular endothelial growth factor-toxin conjugate. Int J Cancer 1997;73:865-870.

21 Sasaki M, Wizigmann-Voos S, Risau W, Plate KH Retrovirus producer cells encoding antisense VEGF prolong survival of rats with intracrania GS9L gliomas. Int J Dev Neurosci 1999;17:579-591.

22 D'Angelo G, Struman I, Martial J, Weiner RI: Activation of mitogen-activated protein kinases by vascular endothelial growth factor and basic fibroblast growth factor in capillary endothelial cells is inhibited by the antiangiogenic factor $16-\mathrm{kDa} \mathrm{N}$-terminal fragment of prolactin. Proc Natl Acad Sci USA 1995;92:6374-6378.

23 Dumont DJ, Gradwohl G, Fong GH, Puri MC, Gertsenstein M, Auerbach A, Breitman ML: Dom inant-negative and targeted null mutations in the endothelial receptor tyrosine kinase, tek, reveal a critical role in vasculogenesis of the embryo. Genes Dev 1994;8:1897-1909.

24 Mandriota SJ, Pyke C, Di Sanza C, Quinodoz P, Pittet B, Pepper MS: Hypoxia-inducible angiopoietin2 expression is mimicked by iodonium compounds and occurs in the rat brain and skin in response to systemic hypoxia and tissue ischemia. Am J Pathol 2000;156:2077-2089.

25 Thurston G, Suri C, Smith K, McClain J, Sato TN, Yancopoulos GD, McDonald DM: Leakage-resistant blood vessels in mice transgenically overexpressing angiopoietin-1. Science 1999;286:25112514.

26 Thurston G, Rudge JS, Ioffe E, Zhou H, Ross L, Croll SD, Glazer N, Holash J, McDonald DM, Yancopoulos GD: Angiopoietin-1 protects the adult vasculature against plasma leakage. Nat Med 2000; 6:460-463.
27 Stratmann A, Risau W, Plate KH: Cell type-specific expression of angiopoietin-1 and angiopoietin-2 suggests a role in glioblastoma angiogenesis [see comments]. Am J Pathol 1998;153:1459-1466.

28 Zagzag D, Amirnovin R, Greco MA, Yee H, Holash J, Wiegand SJ, Zabski S, Yancopoulos GD Grumet M: Vascular apoptosis and involution in gliomas precede neovascularization: A novel concept for glioma growth and angiogenesis. Lab Invest 2000;80:837-849.

29 Zagzag D, Hooper A, Friedlander DR, Chan W, Holash J, Wiegand SJ, Yancopoulos GD, Grumet M: In situ expression of angiopoietins in astrocytomas identifies angiopoietin-2 as an early marker of tumor angiogenesis. Exp Neurol 1999;159:391400.

30 Lin P, Polverini P, Dewhirst M, Shan S, Rao PS, Peters K: Inhibition of tumor angiogenesis using a soluble receptor establishes a role for Tie2 in pathologic vascular growth. J Clin Invest 1997;100:20722078.

31 Lin P, Buxton JA, Acheson A, Radziejewski C, Maisonpierre PC, Yancopoulos GD, Channon KM, Hale LP, Dewhirst MW, George SE, Peters KG: Antiangiogenic gene therapy targeting the endothelium-specific receptor tyrosine kinase Tie2. Proc Natl Acad Sci USA 1998;95:8829-8834.

32 Brooks PC, Clark RA, Cheresh DA: Requirement of vascular integrin alpha $v$ beta 3 for angiogenesis Science 1994;264:569-571.

33 Brooks PC, Montgomery AM, Rosenfeld M, Reisfeld RA, Hu T, Klier G, Cheresh DA: Integrin alpha $\mathrm{v}$ beta 3 antagonists promote tumor regression by inducing apoptosis of angiogenic blood vessels. Cell 1994;79:1157-1164.

34 Gladson CL: Expression of integrin alpha v beta 3 in small blood vessels of glioblastoma tumors. J Neuropathol Exp Neurol 1996;55:1143-1149.

35 Paulus W, Tonn JC: Basement membrane invasion of glioma cells mediated by integrin receptors. J Neurosurg 1994;80:515-519.

36 Nakagawa T, Kubota T, Kabuto M, Fujimoto N, Okada Y: Secretion of matrix metalloproteinase-2 (72 kD gelatinase/type IV collagenase $=$ gelatinase A) by malignant human glioma cell lines: Implications for the growth and cellular invasion of the extracellular matrix. J Neurooncol 1996;28:13-24.

37 Tupchong L, Levison DA, Jones AE: Concomitant conjugal gliomas with similar histologic features. Cancer 1985;55:864-869.

38 Deryugina EI, Bourdon MA, Luo GX, Reisfeld RA, Strongin A: Matrix metalloproteinase-2 activation modulates glioma cell migration. J Cell Sci 1997;110:2473-2482.

39 Vince GH, Wagner S, Pietsch T, Klein R, Goldbrunner RH, Roosen K, Tonn JC: Heterogeneous regional expression patterns of matrix metalloproteinases in human malignant gliomas. Int $\mathrm{J}$ Dev Neurosci 1999;17:437-445.

40 Kleiner DE, Stetler-Stevenson WG: Matrix metalloproteinases and metastasis. Cancer Chemother Pharmacol 1999;43(suppl):S42-51:S42-S51.

41 Koivunen E, Arap W, Valtanen H, Rainisalo A, Medina OP, Heikkila P, Kantor C, Gahmberg CG Salo T, Konttinen YT, Sorsa T, Ruoslahti E, Pasqualini R: Tumor targeting with a selective gelatinase inhibitor. Nat Biotechnol 1999;17:768774.

42 Streit M, Velasco P, Brown LF, Skobe M, Richard L, Riccardi L, Lawler J, Detmar M: Overexpression of thrombospondin-1 decreases angiogenesis and inhibits the growth of human cutaneous squamous cell carcinomas. Am J Pathol 1999;155:441-452.
43 Streit M, Riccardi L, Velasco P, Brown LF, Hawighorst $\mathrm{T}$, Bornstein $\mathrm{P}$, Detmar M: Thrombospondin-2: A potent endogenous inhibitor of tumor growth and angiogenesis. Proc Natl Acad Sci USA 1999;96:14888-14893.

44 Dameron KM, Volpert OV, Tainsky MA, Bouck N: Control of angiogenesis in fibroblasts by p53 regulation of thrombospondin-1. Science 1994;265: 1582-1584.

45 Hsu SC, Volpert OV, Steck PA, Mikkelsen T, Polverini PJ, Rao S, Chou P, Bouck NP: Inhibition of angiogenesis in human glioblastomas by chromosome 10 induction of thrombospondin-1. Cancer Res 1996;56:5684-5691.

46 Dawson DW, Volpert OV, Pearce SF, Schneider AJ, Silverstein RL, Henkin J, Bouck NP: Three distinct D-amino acid substitutions confer potent antiangiogenic activity on an inactive peptide derived from a thrombospondin-1 type 1 repeat. Mol Pharmacol 1999;55:332-338.

47 Tolsma SS, Volpert OV, Good DJ, Frazier WA, Polverini PJ, Bouck N: Peptides derived from two separate domains of the matrix protein thrombospondin-1 have anti-angiogenic activity. J Cell Biol 1993;122:497-511.

48 O'Reilly MS, Holmgren L, Shing Y, Chen C, Rosenthal RA, Moses M, Lane WS, Cao Y, Sage EH, Folkman J: Angiostatin: A novel angiogenesis inhibitor that mediates the suppression of metastases by a Lewis lung carcinoma. Cell 1994;79:315328

49 MacDonald NJ, Murad AC, Fogler WE, Lu Y, Sim BK: The tumor-suppressing activity of angiostatin protein resides within kringles 1 to 3 . Biochem Biophys Res Commun 1999;264:469-477.

50 Cao Y, Ji RW, Davidson D, Schaller J, Marti D, Sohndel S, McCance SG, O'Reilly MS, Llinas M, Folkman J: Kringle domains of human angiostatin. Characterization of the anti-proliferative activity on endothelial cells. J Biol Chem 1996;271:2946129467.

51 Cao R, Wu HL, Veitonmaki N, Linden P, Farnebo J, Shi GY, Cao Y: Suppression of angiogenesis and tumor growth by the inhibitor K1-5 generated by plasmin-mediated proteolysis. Proc Natl Acad Sci USA 1999;96:5728-5733.

52 Ito H, Rovira II, Bloom ML, Takeda K, Ferrans VJ, Quyyumi AA, Finkel T: Endothelial progenitor cells as putative targets for angiostatin. Cancer Res 1999;59:5875-5877.

53 Claesson-Welsh L, Welsh M, Ito N, Ito N, AnandApte B, Soker S, Zetter B, O'Reilly M, Folkman J: Angiostatin induces endothelial cell apoptosis and activation of focal adhesion kinase independently of the integrin-binding motif RGD. Proc Natl Acad Sci USA 1998;95:5579-5583.

54 O'Reilly MS, Holmgren L, Shing Y, Chen C, Rosenthal RA, Cao Y, Moses M, Lane WS, Sage $\mathrm{EH}$, Folkman J: Angiostatin: A circulating endothelial cell inhibitor that suppresses angiogenesis and tumor growth. Cold Spring Harb Symp Quant Biol 1994;59:471-482.

55 Kirsch M, Strasser J, Allende R, Bello L, Zhang J, Black PM: Angiostatin suppresses malignant glioma growth in vivo. Cancer Res 1998;58:46544659.

56 Griscelli F, Li H, Bennaceur-Griscelli A, Soria J, Opolon P, Soria C, Perricaudet M, Yeh P, Lu H: Angiostatin gene transfer: Inhibition of tumor growth in vivo by blockage of endothelial cell proliferation associated with a mitosis arrest. Proc Natl Acad Sci USA 1998;95:6367-6372. 
57 Tanaka T, Cao Y, Folkman J, Fine HA: Viral vectortargeted antiangiogenic gene therapy utilizing an angiostatin complementary DNA. Cancer Res 1998;58:3362-3369.

58 Fishel R, Lescoe MK, Rao M, Copeland NG, Jenkins NA, Garber J, Kane M, Kolodner R: The human mutator gene homolog msh2 and its association with hereditary nonpolyposis colon cancer. Cell 1993;75:1027-1038.

59 Mauceri HJ, Hanna NN, Beckett MA, Gorski DH, Staba MJ, Stellato KA, Bigelow K, Heimann R, Gately S, Dhanabal M, Soff GA, Sukhatme VP, Kufe DW, Weichselbaum RR: Combined effects of angiostatin and ionizing radiation in antitumour therapy. Nature 1998;394:287-291.

60 Gorski DH, Mauceri HJ, Salloum RM, Gately S, Hellman S, Beckett MA, Sukhatme VP, Soff GA, Kufe DW, Weichselbaum RR: Potentiation of the antitumor effect of ionizing radiation by brief concomitant exposures to angiostatin. Cancer Res 1998:58:5686-5689.

61 O'Reilly MS, Boehm T, Shing Y, Fukai N, Vasios G, Lane WS, Flynn E, Birkhead JR, Olsen BR, Folkman J: Endostatin: An endogenous inhibitor of angiogenesis and tumor growth. Cell 1997;88:277-285.

62 Dhanabal M, Ramchandran R, Waterman MJ, Lu H, Knebelmann B, Segal M, Sukhatme VP: Endostatin induces endothelial cell apoptosis. J Biol Chem 1999;274:11721-11726.

63 Yamaguchi N, Anand-Apte B, Lee M, Sasaki T, Fukai N, Shapiro R, Que I, Lowik C, Timpl R, Olsen BR: Endostatin inhibits VEGF-induced endothelial cell migration and tumor growth independently of zinc binding. EMBO J 1999;18:4414-4423.

64 Boehm T, Folkman J, Browder T, O'Reilly MS: Antiangiogenic therapy of experimental cancer does not induce acquired drug resistance. Nature 1997; 390:404-407.

65 Yokoyama Y, Dhanabal M, Griffioen AW, Sukhatme VP, Ramakrishnan S: Synergy between angiostatin and endostatin: Inhibition of ovarian cancer growth. Cancer Res 2000;60:2190-2196.

66 Hosang M: Suramin binds to platelet-derived growth factor and inhibits its biological activity. J Cell Biochem 1985;29:265-273.

67 Bocci G, Danesi R, Benelli U, Innocenti F, Di Paolo A, Fogli S, Del Tacca M: Inhibitory effect of suramin in rat models of angiogenesis in vitro and in vivo. Cancer Chemother Pharmacol 1999;43:205212.
68 Gagliardi AR, Kassack M, Kreimeyer A, Muller G, Nickel P, Collins DC: Antiangiogenic and antiproliferative activity of suramin analogues. Cancer Chemother Pharmacol 1998;41:117-124.

69 Bernsen HJ, Rijken PF, Peters JP, Bakker JH, Boerman RH, Wesseling P, van der Kogel AJ: Suramin treatment of human glioma xenografts; effects on tumor vasculature and oxygenation status. J Neurooncol 1999;44:129-136.

70 Coomber BL: Suramin inhibits C6 glioma-induced angiogenesis in vitro. J Cell Biochem 1995;58:199207.

71 Firsching A, Nickel P, Mora P, Allolio B: Antiproliferative and angiostatic activity of suramin analogues. Cancer Res 1995;55:4957-4961.

72 Schrell UM, Gauer S, Kiesewetter F, Bickel A, Hren J, Adams EF, Fahlbusch R: Inhibition of proliferation of human cerebral meningioma cells by suramin: Effects on cell growth, cell cycle phases, extracellular growth factors, and PDGF-BB autocrine growth loop. J Neurosurg 1995;82:600-607.

73 Ingber D, Fujita T, Kishimoto S, Sudo K, Kanamaru T, Brem H, Folkman J: Synthetic analogues of fumagillin that inhibit angiogenesis and suppress tumour growth. Nature 1990;348:555-557.

74 Castronovo V, Belotti D: TNP-470 (AGM-1470) Mechanisms of action and early clinical development. Eur J Cancer 1996;32A:2520-2527.

75 Maier JA, Delia D, Thorpe PE, Gasparini G: In vitro inhibition of endothelial cell growth by the antiangiogenic drug AGM-1470 (TNP-470) and the anti-endoglin antibody TEC-11. Anticancer Drugs 1997;8:238-244.

76 Hasuike T, Hino M, Yamane T, Nishizawa Y, Mori $\mathrm{H}$, Tatsumi N: Effects of TNP-470, a potent angiogenesis inhibitor, on growth of hematopoietic progenitors [letter]. Eur J Haematol 1997;58:293-294.

77 Isobe N, Uozumi T, Kurisu K, Kawamoto K: Antitumor effect of TNP-470 on glial tumors transplanted in rats. Anticancer Res 1996;16:71-76.

78 Isobe N, Uozumi T, Kurisu K, Kawamoto K: Experimental studies of the antitumor effect of TNP470 on malignant brain tumors. Antitumor effect of TNP-470 on a human medulloblastoma xenograft line. Neuropediatrics 1996;27:136-142.

79 Takechi A, Uozumi T, Kawamoto K, Ito A, Kurisu K, Sudo K: Inhibitory effect of TNP-470, a new anti-angiogenic agent, on the estrogen induced rat pituitary tumors. Anticancer Res 1994;14:157-162.
80 Taki T, Ohnishi T, Arita N, Hiraga S, Saitoh Y, Izumoto S, Mori K, Hayakawa T: Anti-proliferative effects of TNP-470 on human malignant glioma in vivo: Potent inhibition of tumor angiogenesis. J Neurooncol 1994:19:251-258.

81 Wassberg E, Pahlman S, Westlin JE, Christofferson $\mathrm{R}$ : The angiogenesis inhibitor TNP-470 reduces the growth rate of human neuroblastoma in nude rats. Pediatr Res 1997;41:327-333.

82 Yazaki T, Takamiya Y, Costello PC, Mineta T, Menon AG, Rabkin SD, Martuza RL: Inhibition of angiogenesis and growth of human non-malignant and malignant meningiomas by TNP-470. J Neurooncol 1995;23:23-29.

83 D'Amato RJ, Loughnan MS, Flynn E, Folkman J: Thalidomide is an inhibitor of angiogenesis. Proc Natl Acad Sci USA 1994;91:4082-4085.

84 Moreira AL, Friedlander DR, Shif B, Kaplan G, Zagzag D: Thalidomide and a thalidomide analogue inhibit endothelial cell proliferation in vitro. $\mathrm{J}$ Neurooncol 1999;43:109-114.

85 Minchinton AI, Fryer KH, Wendt KR, Clow KA, Hayes MM: The effect of thalidomide on experimental tumors and metastases. Anticancer Drugs 1996;7:339-243.

86 Eisen T, Boshoff C, Mak I, Sapunar F, Vaughan MM, Pyle L, Johnston SR, Ahern R, Smith IE, Gore ME: Continuous low dose Thalidomide: A phase II study in advanced melanoma, renal cell, ovarian and breast cancer. Br J Cancer 2000;82: 812-817.

87 Juliusson G, Celsing F, Turesson I, Lenhoff S, Adriansson M, Malm C: Frequent good partial remissions from thalidomide including best response ever in patients with advanced refractory and relapsed myeloma [In Process Citation]. Br J Haematol 2000;109:89-96.

88 Zomas A, Anagnostopoulos N, Dimopoulos MA: Successful treatment of multiple myeloma relapsing after high-dose therapy and autologous transplantation with thalidomide as a single agent. Bone Marrow Transplant 2000;25:1319-1320.

89 Fine HA, Figg WD, Jaeckle K, Wen PY, Kyritsis AP, Loeffler JS, Levin VA, Black PM, Kaplan R, Pluda JM, Yung WK: Phase II trial of the antiangiogenic agent thalidomide in patients with recurrent high-grade gliomas. J Clin Oncol 2000;18:708. 